\title{
Kelayakan Finansial Kereta Bandara New Yogyakarta International Airport dengan Analisis Sensitivitas Terhadap Perubahan Kebutuhan Lahan
}

\author{
Kevin Andrea dan Ervina Ahyudanari \\ Departemen Teknik Sipil, Fakultas Teknik Sipil, Lingkungan dan Kebumian, \\ Institut Teknologi Sepuluh Nopember (ITS) \\ e-mail: ervina@ce.its.ac.id
}

\begin{abstract}
Abstrak-Pada tahun 2011, penumpang Bandara Adisutjipto Yogyakarta dikatakan melebihi kapasitas yaitu mencapai 4 juta penumpang per tahun, melebihi kapasitasnya yaitu 1,2 juta penumpang per tahun. Untuk mengatasi masalah tersebut, PT. Angkasa Pura 1 memutuskan untuk membangun Bandara New Yogyakarta International Airport yang terletak di Wates, .K.abupaten Kulon Progo. Akses bandara ini difasilitasi moda kereta api. Dalam perencanaan yang ada, terdapat dua desain trase yang berbeda yang disajikan oleh PT. Angkasa Pura 1. Oleh karena itu, dibutuhkan analisa kelayakan finansial kereta bandara NYIA dengan memperhatikan perubahan kebutuhan lahan pada kedua desain trase. Dari data-data yang didapat, dilakukan perhitungan jumlah penumpang kereta Bandara NYIA dengan hasil $\mathbf{7 7 , 8 9 \%}$ penumpang Bandara NYIA menggunakan kereta bandara. Setelah itu dilakukan analisis biaya investasi untuk kedua rute. Investasi untuk trase 1 sebesar Rp544,973,487,977 dan investasi untuk trase 2 adalah Rp1,145,963,930,152.92. Setelah itu dilakukan kelayakan finansial metode NPV, BCR dan IRR untuk kedua trase. Perhitungan kelayakan secara finansial menunjukkan nilai NPV untuk trase 1 adalah Rp10,791,607,297,048.50 sedangkan nilai NPV untuk trase 2 adalah Rp10,333,668,097,720.70. Nilai BCR untuk trase 1 adalah 9.797 sedangkan nilai BCR untuk trase 2 adalah 6.626. Nilai IRR untuk trase 1 adalah $112.68 \%$ sedangkan nilai IRR untuk trase 2 adalah $58.28 \%$. Berdasarkan perhitungan kelayakan secara finansial, trase 1 kereta bandara memiliki nilai kelayakan finansial yg lebih baik dari trase 2 .
\end{abstract}

Kata Kunci- Analisis Demand, NYIA, Kelayakan Finansial, BCR, NPV, IRR

\section{PENDAHULUAN}

$\mathrm{D}$ AERAH Istimewa Yogyakarta merupakan daerah setingkat provinsi di Indonesia yang terkenal sebagai kota pariwisata. Banyaknya objek pariwisata di Yogyakarta telah menarik banyak wisatawan baik domestik maupun mancanegara. Tingginya minat pariwisata di Daerah Istimewa Yogyakarta ini mengharuskan kota ini memiliki akses yang baik, salah satunya adalah moda transportasi udara. Aktivitas Bandara Adisucipto setiap tahunnya terus mengalami peningkatan, baik dari jumlah penumpang, kargo, maupun pesawat. Sejak tahun 2011 Bandara Adisucipto sudah dikatakan kelebihan penumpang dengan jumlah penumpang mencapai 4 juta lebih per tahunnya.

Dengan berbagai pertimbangan yang telah dijelaskan, akhirnya Menteri Perhubungan bersama dengan Gubernur Daerah Istimewa Yogyakarta memutuskan untuk memindahkan Bandara ke Kabupaten Kulonprogo, tepatnya di Kecamatan Temon. Bandara baru ini akan diberi nama New Yogyakarta International Airport (NYIA). Moda transportasi kereta api dinilai menjadi moda transportasi utama untuk daya dukung aksesibilitas penumpang Bandara New Yogyakarta International Airport.

Dalam perencanaan yang ada, terdapat dua desain trase yang berbeda yang disajikan oleh PT Angkasa Pura 1. Oleh karena itu, dibutuhkan analisa kelayakan finansial kereta bandara NYIA dengan memperhatikan perubahan kebutuhan lahan pada kedua desain trase. Untuk mengetahui trase mana yang memberikan tingkat kelayakan lebih tinggi, perlu dilakukan analisis demand penumpang kereta bandara NYIA untuk kedua rute, analisis biaya investasi kereta Bandara NYIA untuk kedua rute dan analisis kelayakan finansial kereta Bandara NYIA untuk kedua rute. Hasil yang diharapkan dari studi ini adalah dapat ditentukan trase yang memiliki potensi kelayakan terbesar dari kedua alternatif trase yang ada.

Kereta api bandara sudah menjadi kebutuhan untuk sebagian bandara besar di Indonesia. Hal ini sudah menjadi topik peneliti di beberapa bandara baru [1].

\section{METODE}

Penelitian dimulai terlebih dahulu dari latar belakang kenapa penelitian ini dilakukan. Kemudian dilakukan studi literatur yang terkait dengan penelitian ini.

Demand kereta bandara NYIA didapatkan dari perhitungan travel time, travel cost, dan total nilai penghematan. Pengumpulan data untuk travel time diambil dari Google Maps setiap jam selama 24 jam. Travel time dilakukan pada tiga kondisi, yaitu:

1.Zona Asal menuju Bandara NYIA menggunakan kendaraan pribadi. 
2.Zona Asal menuju Stasiun Tugu menggunakan kendaraan pribadi, lalu menggunakan kereta bandara NYIA trase 1 dan 2 menuju Bandara NYIA.

3.Zona Asal menuju Stasiun Tugu menggunakan kendaraan pribadi, lalu menggunakan kereta Prambanan Ekspres menuju Stasiun Kedundang, lalu menggunakan kereta bandara NYIA melewati Trase $1 \& 2$ menuju Bandara NYIA.

Setelah dilakukan pengumpulan data, dilakukan perbandingan antara kondisi 1-kondisi 2 dan kondisi 1-kondisi 3.

Analisis travel cost dilakukan menggunakan metode jasa marga dan pada kondisi yang sama dengan analisis travel time.

Setelah itu dilakukan total nilai penghematan untuk tiap daerah tiap jam menggunakan nilai Willingness to Pay untuk pengurangan waktu perjalanan menuju bandara. Total nilai penghematan dapat dilakukan dengan rumus seperti berikut:

Total Penghematan $=$ Penghematan Travel Cost + (Penghematan Travel Time x Nilai WTP)

Untuk kondisi yang mengalami nilai penghematan positif, maka diasumsikan pindah moda menggunakan kereta bandara NYIA.

Jumlah penumpang kereta bandara per tahun didapatkan dengan rumus sebagai berikut:

Jumlah penumpang kereta bandara $=(\mathrm{A} \times \mathrm{B} \times \mathrm{C}) \times \mathrm{D}$

Dimana:

A : Persentase Penumpang pada Jam Keberangkatan Pesawat.

B : Persentase Penumpang Tiap Zona.

C : Persentase Penumpang Berdasarkan Tujuan Penerbangan.

D : Jumlah Penumpang Bandara Per Tahun.

Biaya investasi terdiri dari biaya pembebasan lahan, biaya pembangunan jalan rel dan biaya wagon. Perhitungan pembebasan lahan dilakukan membagi lahan yang dibutuhkan menjadi tiga jenis, yaitu tanah kosong, sawah dan rumah menggunakan aplikasi AutoCad. Luas untuk masing-masing jenis lahan lalu dikalikan dengan harga asumsi yang diambil.

Biaya pembangunan jalan rel menggunakan asumsi sebesar Rp. 25.649.474.962 per km' sp [2]. Setelah disesuaikan dn0

Biaya wagon kereta didapatkan dengan perhitungan jumlah wagon yang dibutuhkan selama umur rencana, lalu dikalikan dengan harga asumsi kereta yang dipakai yaitu kereta Madiun Jaya Ekspres dengan harga Rp. 7.250.000.000 per unit kereta [3].

Perhitungan kelayakan finansial dilakukan dengan 3 metode yaitu metode NPV, BCR dan IRR. Setelah didapatkan nilai kelayakan finansial untuk kedua trase maka dipilih trase yang memiliki nilai kelayakan finansial yang lebih baik.

Gambar 1 menunjukkan diagram alir pengerjaan studi.

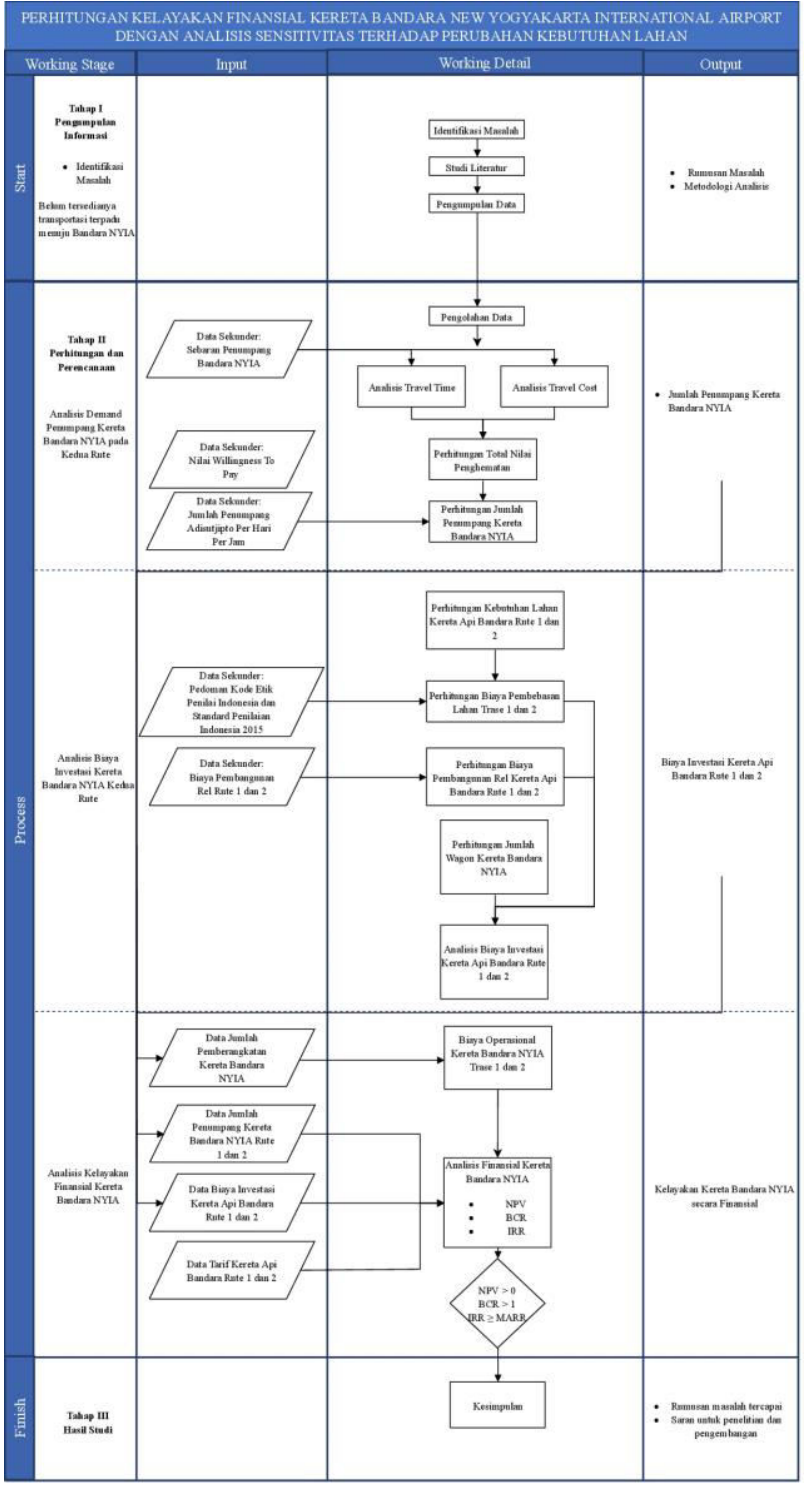

Gambar 1. Diagram Alir.

Tabel 1.

Jam Puncak (Andrea, 2018)

\begin{tabular}{|c|c|c|c|}
\hline Daerah Asal & Jam Puncak Kondisi 1 & Jam Puncak Kondisi & Jam Puncak Kondisi \\
& & 2 & 3 \\
\hline Yogyakarta & $17: 00$ & $20: 00$ & $17: 00$ \\
\hline Sleman & $10: 00$ & $15: 00-17: 00$ & $16: 00$ \\
\hline Bantul & $7: 00$ & $16: 00-17: 00$ & $16: 00$ \\
\hline Klaten & $16: 00$ & $18: 00$ & $15: 00$ \\
\hline Kulon Progo & $7: 00$ & $13: 00-16: 00$ & $16: 00$ \\
\hline Kebumen & $7: 00$ & $13: 00-15: 00$ & $14: 00$ \\
\hline Magelang & $8: 00$ & $13: 00-15: 00$ & $15: 00$ \\
\hline Surakarta & $16: 00$ & $16: 00-17: 00$ & $14: 00$ \\
\hline Banyumas & $15: 00$ & $15: 00$ & $12: 00$ \\
\hline Gunung Kidul & $7: 00$ & $19: 00$ & $11: 00$ \\
\hline Temanggung & $13: 00$ & $9: 00-15: 00$ & $11: 00$ \\
\hline Purworejo & $06: 00-08: 00$ & $15: 00-16: 00$ & $15: 00$ \\
\hline Sragen & $14: 00$ & $12: 00$ & $10: 00$ \\
\hline Cilacap & $15: 00$ & $11: 00$ & $12: 00$ \\
\hline Wonosobo & $13: 00$ & $14: 00$ & $14: 00$ \\
\hline Sukoharjo & $15: 00$ & $17: 00-18: 00$ & $15: 00$ \\
\hline Ngawi & $13: 00$ & $13: 00-14: 00$ & $8: 00$ \\
\hline
\end{tabular}




\section{HASIL DAN PEMBAHASAN}

\section{A. Analisis Demand}

\section{Perhitungan Travel Time}

Berdasarkan hasil perhitungan travel time menggunakan Google Maps, didapatkan jam puncak untuk tiap kondisi, penghematan waktu kondisi 2 terhadap kondisi 1 dan penghematan waktu kondisi 3 terhadap kondisi 1 . Tabel 1 menunjukkan jam puncak untuk tiap zona dan kondisi.

Tabel 2 menunjukkan penghematan waktu terbesar kondisi 2 terhadap kondisi 1 . Tabel 3 menunjukkan penghematan waktu terbesar kondisi 3 terhadap kondisi 1.

Tabel 2.

Penghematan Waktu Terbesar Kondisi 2 Terhadap Kondisi 1 (Andrea, 2018)

\begin{tabular}{|c|c|c|}
\hline Daerah Asal & $\begin{array}{c}\text { Jam Penghematan } \\
\text { Terbesar }\end{array}$ & $\begin{array}{c}\text { Jumlah } \\
\text { Penghematan }\end{array}$ \\
\hline Yogyakarta & $9: 00$ & 29 Menit \\
\hline Sleman & $9: 00$ & 18 Menit \\
\hline Bantul & - & - \\
\hline Klaten & $16: 00$ & 11 Menit \\
\hline Kulon Progo & - & - \\
\hline Kebumen & - & - \\
\hline Magelang & - & - \\
\hline Surakarta & $21: 00$ & 4 Menit \\
\hline Banyumas & - & - \\
\hline Gunung Kidul & - & - \\
\hline Temanggung & $1: 00-3: 00$ & 1 Menit \\
\hline Purworejo & - & - \\
\hline Sragen & - & - \\
\hline Cilacap & - & - \\
\hline Wonosobo & - & - \\
\hline Sukoharjo & $15: 00$ & 19 Menit \\
\hline Ngawi & $13: 00$ & 12 Menit \\
\hline
\end{tabular}

Tabel 3.

Penghematan Waktu Terbesar Kondisi 3 Terhadap Kondisi 1 (Andrea, 2018)

\begin{tabular}{|c|c|c|}
\hline Daerah Asal & $\begin{array}{c}\text { Jam Penghematan } \\
\text { Terbesar }\end{array}$ & $\begin{array}{c}\text { Jumlah Penghematan } \\
\text { Terbesar Antara }\end{array}$ \\
\hline Yogyakarta & $17: 00$ & 7 Menit \\
\hline Sleman & $12: 00$ & 3 Menit \\
\hline Bantul & - & - \\
\hline Klaten & - & - \\
\hline Kulon Progo & - & - \\
\hline Kebumen & - & - \\
\hline Magelang & - & - \\
\hline Surakarta & $3: 00$ & 1.5 Menit \\
\hline Banyumas & - & - \\
\hline Gunung Kidul & - & - \\
\hline Temanggung & - & - \\
\hline Purworejo & - & - \\
\hline Sragen & - & - \\
\hline Cilacap & - & - \\
\hline Wonosobo & - & - \\
\hline Sukoharjo & - & - \\
\hline Ngawi & - & - \\
\hline
\end{tabular}

\section{Perhitungan Travel Cost}

Berdasarkan hasil perhitungan travel cost pada tiga kondisi, didapatkan penghematan biaya kondisi 2 terhadap kondisi 1 dan penghematan biaya kondisi 3 terhadap kondisi 1. Tabel 4 menunjukkan penghematan biaya terbesar kondisi 2 terhadap kondisi 1 dan Tabel 5 menunjukkan penghematan biaya terbesar kondisi 3 terhadap kondisi 1.
Tabel 4.

Penghematan Biaya Terbesar Kondisi 2 Terhadap Kondisi 1 (Andrea, 2018)

\begin{tabular}{|c|c|c|}
\hline Daerah Asal & $\begin{array}{c}\text { Jam Penghematan } \\
\text { Terbesar }\end{array}$ & $\begin{array}{c}\text { Jumlah Penghematan Terbesar } \\
\text { Antara Kasus 1 dan 2 }\end{array}$ \\
\hline Yogyakarta & $17: 00$ & Rp37,379 \\
\hline Sleman & $9: 00$ & Rp34,680 \\
\hline Bantul & - & - \\
\hline Klaten & $16: 00$ & Rp34,281 \\
\hline Kulon Progo & - & - \\
\hline Kebumen & - & - \\
\hline Magelang & $4: 00$ & Rp6,255 \\
\hline Surakarta & $21: 00$ & Rp30,875 \\
\hline Banyumas & - & - \\
\hline Gunung Kidul & $2: 00$ & Rp14,352 \\
\hline Temanggung & - & - \\
\hline Purworejo & - & - \\
\hline Sragen & $0: 00$ & Rp20,450 \\
\hline Cilacap & - & - \\
\hline Wonosobo & - & - \\
\hline Sukoharjo & $15: 00$ & Rp52,066 \\
\hline Ngawi & - & - \\
\hline
\end{tabular}

Tabel 5.

Penghematan Biaya Terbesar Kondisi 2 Terhadap Kondisi 1 (Andrea, 2018)

\begin{tabular}{|c|c|c|}
\hline Daerah Asal & $\begin{array}{c}\text { Jam Penghematan } \\
\text { Terbesar }\end{array}$ & $\begin{array}{c}\text { Jumlah Penghematan Terbesar } \\
\text { Antara Kasus 1 dan 3 }\end{array}$ \\
\hline Yogyakarta & $17: 00$ & Rp89,379 \\
\hline Sleman & $12: 00$ & Rp86,259 \\
\hline Bantul & $4: 00$ & Rp27,872 \\
\hline Klaten & $15: 00$ & Rp142,002 \\
\hline Kulon Progo & - & - \\
\hline Kebumen & - & - \\
\hline Magelang & $3: 00$ & Rp58,639 \\
\hline Surakarta & $3: 00$ & Rp85,326 \\
\hline Banyumas & - & - \\
\hline Gunung Kidul & $3: 00$ & Rp64,143 \\
\hline Temanggung & $3: 00$ & Rp48,829 \\
\hline Purworejo & - & - \\
\hline Sragen & $2: 00$ & Rp85,522 \\
\hline Cilacap & - & - \\
\hline Wonosobo & - & - \\
\hline Sukoharjo & $2: 00$ & Rp85,655 \\
\hline Ngawi & $2: 00$ & Rp76,250 \\
\hline
\end{tabular}

\section{Perhitungan Jumlah Penumpang Kereta Bandara NYIA}

Nilai Willingness to Pay (WTP) yang dijadikan asumsi adalah 90,08 €/jam untuk tujuan perjalanan bisnis dan 45,8 $€ /$ jam untuk tujuan perjalanan non-bisnis [3]. Nilai WTP tersebut didapatkan dari penelitian yang dilakukan di Belanda. Untuk menyesuaikan nilai WTP, dilakukan konversi nilai menggunakan perbandingan nilai pendapatan per kapita antara Belanda dan Indonesia. Berikut adalah konversi nilai WTP untuk tujuan perjalanan bisnis dan non-bisnis:

$$
\begin{aligned}
& \text { WTPbisnis }=\frac{3.603,74}{45.502,45} \times R p .1 .456 .920 \\
& \text { WTPbisnis }=R p .115 .377,- \\
& \text { WTPnonbisnis }=\frac{3.603,74}{45.502,45} \times \text { Rp. } 741.410 \\
& \text { WTPnonbisnis }=R p .58 .714,-
\end{aligned}
$$

Berikut adalah contoh perhitungan total nilai penghematan tujuan bisnis untuk trase 1 zona Yogyakarta pada jam 04:00: 
Total Penghematan $=$ Penghematan Travel Cost + (Penghematan Travel Time $\mathrm{x}$ Nilai WTP)

Total Penghematan $=$ Rp. $26.270+(0.17$ jam $x$ Rp. 115.377$)$

Total Penghematan= Rp. 45.499

Setelah dilakukan perhitungan total nilai penghematan pada tiap kondisi dan daerah yang potensial, maka dilakukan perhitungan jumlah penumpang kereta Bandara NYIA. Perhitungan jumlah penumpang kereta bandara dilakukan pada daerah yang nilai total penghematannya adalah positif. Tabel 6 menunjukkan persentase jumlah penumpang kereta Bandara NYIA terhadap jumlah penumpang Bandara NYIA.

Tabel 6.

Persentase Jumlah Penumpang Kereta Bandara NYIA [4]

\begin{tabular}{|c|c|c|c|c|}
\hline Daerah & $\begin{array}{l}\text { Persentase Penumpang } \\
\text { Bandara pada Jam } \\
\text { Keberangkatan Pesawat } \\
\text { (Diasumsikan } 1 \text { jam } \\
\text { setelah jam kedatangan di } \\
\text { NYIA) }\end{array}$ & $\begin{array}{c}\text { Persentase Jumlah } \\
\text { Penumpang/Zona }\end{array}$ & \begin{tabular}{|c} 
Persentase \\
Penumpang \\
Berdasarkan Tujuan \\
Penerbangan
\end{tabular} & $\begin{array}{c}\text { Persentase } \\
\text { Penumpang } \\
\text { Kereta dari Total } \\
\text { Penumpang } \\
\text { Bandara }\end{array}$ \\
\hline & (1) & (2) & (3) & (1) $\times(2) \times(3)$ \\
\hline Yogyakarta & $100.0 \%$ & $42.58 \%$ & $100.00 \%$ & $42.58 \%$ \\
\hline Sleman & $100.0 \%$ & $25.48 \%$ & $100.00 \%$ & $25.48 \%$ \\
\hline Klaten & $100.0 \%$ & $5.16 \%$ & $100.00 \%$ & $5.16 \%$ \\
\hline \multirow{3}{*}{ Magelang } & $10.4 \%$ & \multirow{3}{*}{$2.90 \%$} & $71.0 \%$ & $0.21 \%$ \\
\hline & $5.6 \%$ & & $71.0 \%$ & $0.12 \%$ \\
\hline & $8.3 \%$ & & $71.0 \%$ & $0.17 \%$ \\
\hline Surakarta & $100.0 \%$ & $2.90 \%$ & $100.00 \%$ & $2.90 \%$ \\
\hline \multirow{6}{*}{ Gunung Kidul } & $1.02 \%$ & \multirow{6}{*}{$1.29 \%$} & $100.00 \%$ & $0.01 \%$ \\
\hline & $8.65 \%$ & & $100.00 \%$ & $0.11 \%$ \\
\hline & $10.38 \%$ & & $100.00 \%$ & $0.13 \%$ \\
\hline & $5.59 \%$ & & $71.0 \%$ & $0.05 \%$ \\
\hline & $8.1 \%$ & & $71.0 \%$ & $0.07 \%$ \\
\hline & $9.52 \%$ & & $71.0 \%$ & $0.09 \%$ \\
\hline Temanggung & $10.4 \%$ & $0.97 \%$ & $100.0 \%$ & $0.10 \%$ \\
\hline \multirow{9}{*}{ Sragen } & $1.0 \%$ & \multirow{9}{*}{$0.65 \%$} & $100.0 \%$ & $0.01 \%$ \\
\hline & $8.7 \%$ & & $100.0 \%$ & $0.06 \%$ \\
\hline & $10.4 \%$ & & $100.0 \%$ & $0.07 \%$ \\
\hline & $5.6 \%$ & & $71.0 \%$ & $0.03 \%$ \\
\hline & $6.3 \%$ & & $71.0 \%$ & $0.03 \%$ \\
\hline & $8.2 \%$ & & $71.0 \%$ & $0.04 \%$ \\
\hline & $12.4 \%$ & & $71.0 \%$ & $0.06 \%$ \\
\hline & $6.6 \%$ & & $100.0 \%$ & $0.04 \%$ \\
\hline & $0.1 \%$ & & $71.0 \%$ & $0.00 \%$ \\
\hline Sukoharjo & $100.0 \%$ & $0.32 \%$ & $100.0 \%$ & $0.32 \%$ \\
\hline \multirow{3}{*}{ Ngawi } & $10.4 \%$ & \multirow{3}{*}{$0.32 \%$} & $71.0 \%$ & $0.02 \%$ \\
\hline & $5.6 \%$ & & $71.0 \%$ & $0.01 \%$ \\
\hline & $6.6 \%$ & & $71.0 \%$ & $0.02 \%$ \\
\hline \multicolumn{4}{|c|}{ Total Penumpang Kereta Bandara NYIA } & $77.89 \%$ \\
\hline
\end{tabular}

Gambar 2 menunjukkan jumlah penumpang kereta Bandara NYIA selama umur rencana 20 tahun.

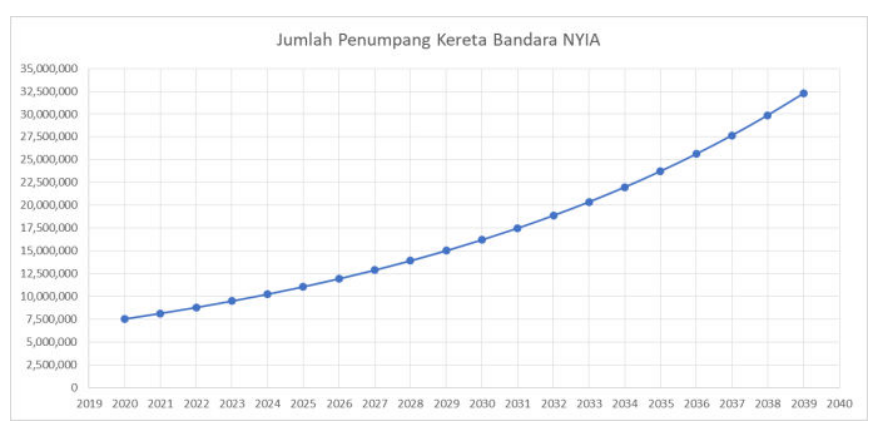

Gambar 2. Jumlah Penumpang Kereta Bandara NYIA Selama Umur Rencana (Andrea, 2018)

\section{B. Analisis Biaya Investasi}

1. Perhitungan Biaya Pembebasan Lahan

Kebutuhan lahan untuk trase 1 adalah $92.090 \mathrm{~m} 2=9.2$ ha dengan rincian sebagai berikut:

- Rumah : $9.784 \mathrm{~m} 2$

- Tanah Kosong : 39.365 m2

- Sawah : $42.941 \mathrm{~m} 2$

Kebutuhan lahan untuk trase 2 adalah $274.689 \mathrm{~m} 2=27.46$ ha dengan rincian sebagai berikut:

- Rumah : $9.246 \mathrm{~m} 2$

- Tanah Kosong : $84.212 \mathrm{~m} 2$

- Sawah : $181.231 \mathrm{~m} 2$

Dengan asumsi harga rumah sebesar Rp. 8.085.106/m2, harga tanah kosong sebesar Rp. 3.000.000/m2 dan harga sawah sebesar Rp. 2.800.000/m2, didapatkan biaya pembebasan lahan untuk kedua trase. Tabel 7 menunjukkan biaya pembebasan lahan untuk trase 1 .

Tabel 7.

Biaya Pembebasan Lahan Trase 1 [4]

\begin{tabular}{|c|c|c|c|}
\hline Jenis Lahan & Luas Lahan & Harga Asumsi & Biaya Pembebasan Lahan \\
\hline & $(\mathrm{m} 2)$ & $(\mathrm{Rp})$ & $(\mathrm{Rp})$ \\
\hline Rumah & 9784 & $\mathrm{Rp} 8,085,106.00$ & $\mathrm{Rp} 79,104,677,104.00$ \\
\hline Tanah Kosong & 39365 & $\mathrm{Rp} 3,000,000.00$ & $\mathrm{Rp} 118,095,000,000.00$ \\
\hline Sawah & 42941 & $\mathrm{Rp} 2,800,000.00$ & $\mathrm{Rp} 120,234,800,000.00$ \\
\hline \multicolumn{3}{|c|}{ TOTAL } & $\mathrm{Rp} 317,434,477,104.00$ \\
\hline
\end{tabular}

Tabel 8 menunjukkan biaya pembebasan lahan untuk trase 2 .

Tabel 8.

Biaya Pembebasan Lahan Trase 2 [4]

\begin{tabular}{|c|c|c|c|}
\hline Jenis Lahan & Luas Lahan & Harga Asumsi & Biaya Pembebasan Lahan \\
\hline & $(\mathrm{m} 2)$ & $(\mathrm{Rp})$ & $(\mathrm{Rp})$ \\
\hline Rumah & 9246 & $\mathrm{Rp} 8,085,106.00$ & $\mathrm{Rp} 74,754,890,076.00$ \\
\hline Tanah Kosong & 84212 & $\mathrm{Rp} 3,000,000.00$ & $\mathrm{Rp} 252,636,000,000.00$ \\
\hline Sawah & 181231 & $\mathrm{Rp} 2,800,000.00$ & $\mathrm{Rp} 507,446,800,000.00$ \\
\hline \multicolumn{3}{|c|}{ TOTAL } & $\mathrm{Rp} 834,837,690,076.00$ \\
\hline
\end{tabular}

2. Perhitungan Biaya Pembangunan Rel dan Biaya Wagon Kereta Api

Tabel 9.

Jumlah Wagon Kereta Selama Umur Rencana (Andrea, 2018)

\begin{tabular}{|c|c|c|}
\hline Tahun & Jumlah Kereta Per Rangkaian & $\begin{array}{c}\text { Jumlah } \\
\text { Pemberangkatan/Hari }\end{array}$ \\
\hline 2020 & 10 & 39 \\
\hline 2021 & 10 & 39 \\
\hline 2022 & 10 & 39 \\
\hline 2023 & 10 & 39 \\
\hline 2024 & 11 & 39 \\
\hline 2025 & 12 & 39 \\
\hline 2026 & 13 & 39 \\
\hline 2027 & 14 & 39 \\
\hline 2028 & 14 & 58 \\
\hline 2029 & 14 & 58 \\
\hline 2030 & 14 & 58 \\
\hline 2031 & 14 & 58 \\
\hline 2032 & 14 & 58 \\
\hline 2033 & 14 & 58 \\
\hline 2034 & 15 & 77 \\
\hline 2035 & 15 & 77 \\
\hline 2036 & 15 & 77 \\
\hline 2037 & 15 & 77 \\
\hline 2038 & 16 & 77 \\
\hline 2039 & 17 & 77 \\
\hline & & \\
\hline
\end{tabular}


Jumlah wagon kereta yang dibutuhkan selalu meningkat selama umur rencana sesuai dengan jumlah penumpang kereta Bandara NYIA. Tabel 9 menunjukkan jumlah wagon kereta yang dibutuhkan selama umur rencana.

Gambar 3 menunjukkan kapasitas kereta Bandara NYIA dan jumlah penumpang kereta Bandara NYIA.

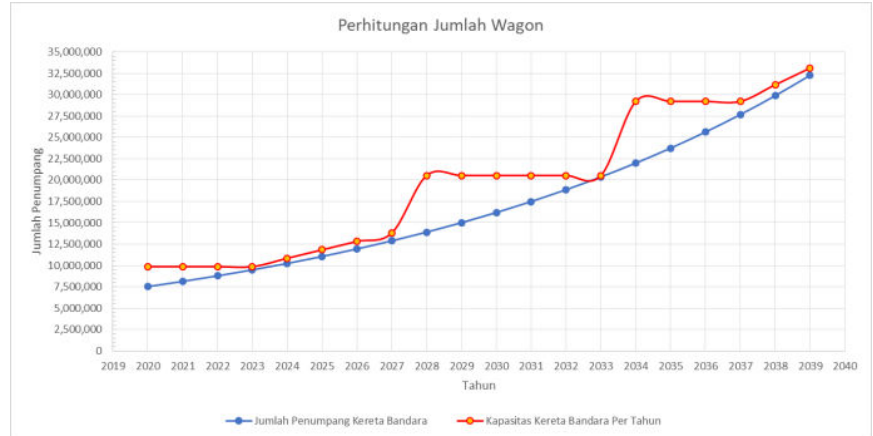

Gambar 3. Kapasitas Kereta Bandara NYIA dan Jumlah Penumpang Kereta Bandara NYIA per Tahun (Andrea, 2018)

3. Total Biaya Investasi

Gambar 4 menunjukkan total biaya investasi kereta Bandara NYIA trase 1 dan 2.

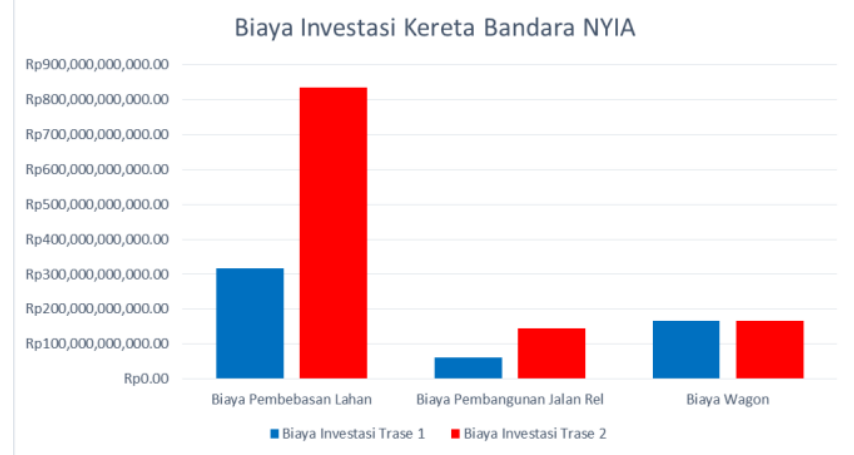

Gambar 4. Biaya Investasi Trase 1 dan 2 (Andrea, 2018)

\section{Analisis Kelayakan Finansial}

1. Perhitungan Biaya Operasional Kereta

Perhitungan biaya operasional kereta menggunakan asumsi dari kereta Madiun Jaya Ekspres. Gambar 5 menunjukkan biaya operasional kereta Bandara NYIA trase 1 dan 2 selama umur rencana 20 tahun.

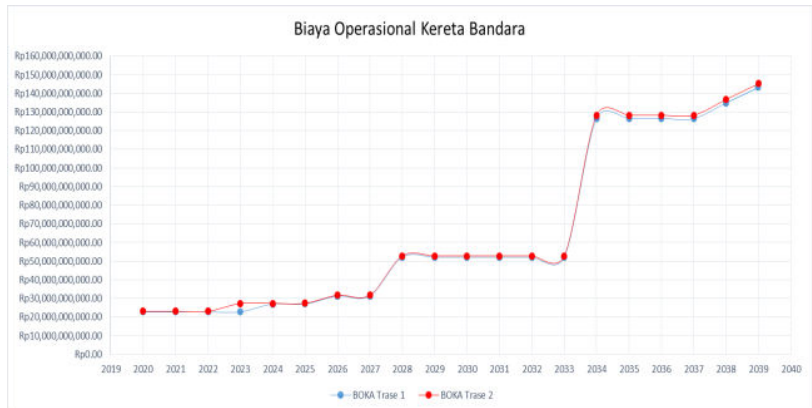

Gambar 5. Biaya Operasional Kereta Bandara NYIA (Andrea, 2018)

\section{Perhitungan Net Present Value}

Nilai present worth cost trase 1 adalah Rp1,226,649,251,239 dan present worth benefit trase 1 adalah Rp12,018,256,548,287.50. Maka, nilai NPV untuk trase 1 adalah Rp10,791,607,297,048.50.

Nilai present worth cost trase 2 adalah Rp1,836,718,280,292 dan present worth benefit trase 2 adalah Rp12,170,386,378,012.70. Maka, nilai NPV untuk trase 2 adalah Rp10,333,668,097,720.70.

3. Perhitungan Benefit Cost Ratio

BCR untuk trase 1 adalah:

$$
B C R=\frac{\text { Benefit }}{\text { Cost }}=\frac{R p 12,018,256,548,287.50}{R p 1,226,649,251,239}=9.797
$$

BCR untuk trase 2 adalah:

$$
B C R=\frac{\text { Benefit }}{\text { Cost }}=\frac{R p 12,170,386,378,012.70}{R p 1,836,718,280,292}=6.626
$$

4. Perhitungan Internal Rate of Return

Gambar 6 menunjukkan perhitungan IRR untuk trase 1 yaitu sebesar $112.68 \%$.

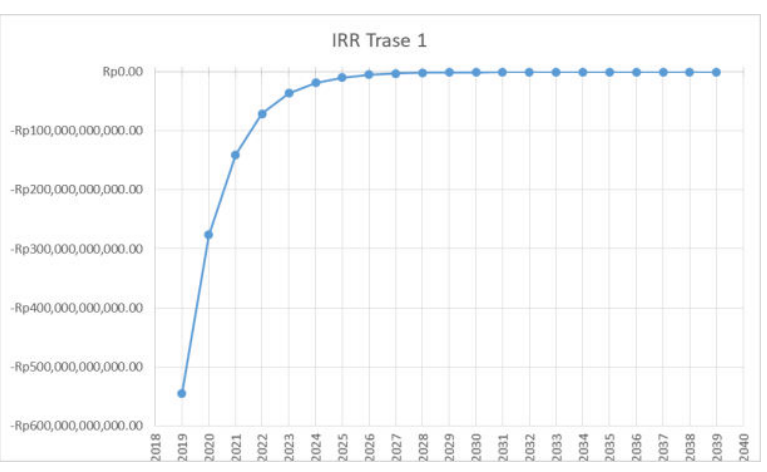

Gambar 6. IRR Trase 1 (Andrea, 2018)

Gambar 7 menunjukkan perhitungan IRR untuk trase 2 yaitu sebesar 58.28\%.

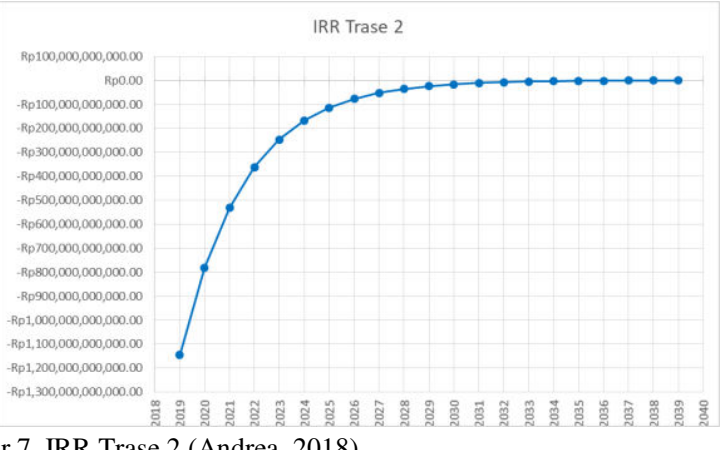

Gambar 7. IRR Trase 2 (Andrea, 2018)

\section{KESIMPULAN}

\section{A. Kesimpulan}

1. Berdasarkan hasil perhitungan travel time dan travel cost, jumlah penumpang Kereta Bandara NYIA sebanyak 77.89\% dari total penumpang di Bandara NYIA. 
2. Berdasarkan hasil perhitungan biaya pembebasan lahan, perhitungan biaya pembangunan jalan rel dan biaya wagon kereta api, total biaya investasi untuk trase 1 adalah Rp544,973,487,977.10. Sedangkan total biaya investasi untuk trase 2 adalah Rp1,145,963,930,152.92.

3. Perhitungan kelayakan secara finansial menunjukkan nilai NPV untuk trase 1 adalah Rp5,320,760,379,876.78 sedangkan nilai NPV untuk trase 2 adalah Rp4,793,569,953,749.28. Nilai BCR untuk trase 1 adalah 5.337 sedangkan nilai BCR untuk trase 2 adalah 3.609. Nilai IRR untuk trase 1 adalah 59.94\% sedangkan nilai IRR untuk trase 2 adalah $32.77 \%$.

4. Berdasarkan perhitungan kelayakan secara finansial, trase 1 kereta bandara memiliki nilai kelayakan finansial yg lebih baik dari trase 2 .

\section{DAFTAR PUSTAKA}

[1] H. Purnama and E. Yuliawati, "Kajian Optimalisasi Bandar Udara International Adi Sumarmo Solo melalui PeningkatanKonektivitas antara Solo-Yogyakarta dengan Angkutan Kereta Api Khusus Bandar Udara," 2014.

[2] Kementerian Perhubungan Republik Indonesia, "Peraturan Menteri Perhubungan Nomor 78 Tahun 2014," 2014.

[3] M. Fricilia and J. Legowo, "Evaluasi Penerapan Tarif Angkutan Umum Kereta Api (Studi Kasus Kereta Api Madiun Jaya Ekspres),” 2013.

[4] K. Andrea, "Perhitungan Kelayakan Finansial Kereta Bandara New Yogyakarta International Airport Dengan Analisis Sensitivitas Terhadap Perubahan Kebutuhan Lahan,”Surabaya, 2018. 